\title{
Monitoring quality and coverage of harm reduction services for people who use drugs: a consensus study
}

\author{
Lucas Wiessing $^{1 *}$ (D), Marica Ferri ${ }^{1}$, Vendula Běláčková2,3,4, Patrizia Carrieri ${ }^{5,6}$, Samuel R. Friedman7, Cinta Folch ${ }^{8,9}$, \\ Kate Dolan ${ }^{10}$, Brian Galvin ${ }^{11}$, Peter Vickerman ${ }^{12}$, Jeffrey V. Lazarus ${ }^{13,14}$, Viktor Mravčík ${ }^{2,3,15}$, Mirjam Kretzschmar ${ }^{16,17}$, \\ Vana Sypsa ${ }^{18}$, Ana Sarasa-Renedo ${ }^{9,19}$, Anneli Uusküla ${ }^{20}$, Dimitrios Paraskevis ${ }^{18}$, Luis Mendão ${ }^{21}$, Diana Rossi ${ }^{22}$, \\ Nadine van Gelder ${ }^{1}$, Luke Mitcheson ${ }^{23}$, Letizia Paoli24,25, Cristina Diaz Gomez ${ }^{26}$, Maitena Milhet ${ }^{26}$, Nicoleta Dascalü ${ }^{27}$, \\ Jonathan Knight ${ }^{28}$, Gordon Hay ${ }^{29}$, Eleni Kalamara', Roland Simon', EUBEST working group, Catherine Comiskey ${ }^{30}$, \\ Carla Rossi ${ }^{31}$ and Paul Griffiths ${ }^{1}$
}

\begin{abstract}
Background and aims: Despite advances in our knowledge of effective services for people who use drugs over the last decades globally, coverage remains poor in most countries, while quality is often unknown. This paper aims to discuss the historical development of successful epidemiological indicators and to present a framework for extending them with additional indicators of coverage and quality of harm reduction services, for monitoring and evaluation at international, national or subnational levels. The ultimate aim is to improve these services in order to reduce health and social problems among people who use drugs, such as human immunodeficiency virus (HIV) and hepatitis C virus (HCV) infection, crime and legal problems, overdose (death) and other morbidity and mortality.
\end{abstract}

Methods and results: The framework was developed collaboratively using consensus methods involving nominal group meetings, review of existing quality standards, repeated email commenting rounds and qualitative analysis of opinions/experiences from a broad range of professionals/experts, including members of civil society and organisations representing people who use drugs. Twelve priority candidate indicators are proposed for opioid agonist therapy (OAT), needle and syringe programmes (NSP) and generic cross-cutting aspects of harm reduction (and potentially other drug) services. Under the specific OAT indicators, priority indicators included 'coverage', 'waiting list time', 'dosage' and 'availability in prisons'. For the specific NSP indicators, the priority indicators included 'coverage', 'number of needles/ syringes distributed/collected', 'provision of other drug use paraphernalia' and 'availability in prisons'. Among the generic or cross-cutting indicators the priority indicators were 'infectious diseases counselling and care', 'take away naloxone', 'information on safe use/sex' and 'condoms'. We discuss conditions for the successful development of the suggested indicators and constraints (e.g. funding, ideology). We propose conducting a pilot study to test the feasibility and applicability of the proposed indicators before their scaling up and routine implementation, to evaluate their effectiveness in comparing service coverage and quality across countries.

Conclusions: The establishment of an improved set of validated and internationally agreed upon best practice indicators for monitoring harm reduction service will provide a structural basis for public health and epidemiological studies and support evidence and human rights-based health policies, services and interventions.

(Continued on next page)

\footnotetext{
* Correspondence: Lucas.Wiessing@emcdda.europa.eu

'European Monitoring Centre for Drugs and Drug Addiction (EMCDDA),

Praça Europa 1, Cais do Sodré, 1249-289 Lisbon, Portugal

Full list of author information is available at the end of the article
}

(c) The Author(s). 2017 Open Access This article is distributed under the terms of the Creative Commons Attribution 4.0 International License (http://creativecommons.org/licenses/by/4.0/), which permits unrestricted use, distribution, and reproduction in any medium, provided you give appropriate credit to the original author(s) and the source, provide a link to the Creative Commons license, and indicate if changes were made. The Creative Commons Public Domain Dedication waiver (http://creativecommons.org/publicdomain/zero/1.0/) applies to the data made available in this article, unless otherwise stated. 
(Continued from previous page)

Keywords: Substance abuse, People who use drugs/PWUD, People who inject drugs/PWID, Injecting drug users/IDU, Best practice, Harm reduction, Knowledge exchange, Interventions, Indicators, Coverage, Epidemiology, HIV, HCV, Monitoring, Evidence-based, Drug services

\section{Background}

Important advances in interventions for people who use drugs (PWUD), in particular those who use opioids and people who inject drugs (PWID), have occurred over recent decades. Harm reduction services such as needle and syringe programmes (NSP) and opioid agonist therapy (OAT) [1] have been increasingly established, with 90 countries having NSP to some degree and 80 at least one OAT programme operational by 2016 [2]. This has contributed to reductions in viral infections (e.g. human immunodeficiency virus (HIV), hepatitis $\mathrm{C}$ virus $(\mathrm{HCV})$ ) and bacterial infections (e.g. tuberculosis (TB), sexually transmissible infections, skin infections), crime, overdose and mortality among PWUD. Health cost savings are being achieved globally, where harm reduction is in place, especially where these services are combined with antiretroviral therapy (ART), allowing millions of people living with HIV to stay healthy [3-15]. The provision of naloxone, a drug to reverse overdose, has expanded from paramedics to drug workers and to PWUD themselves and their peers [16-18]. Treatments for infectious diseases (e.g. HIV, hepatitis B virus (HBV)) and new direct-acting antiviral (DAA) treatments for $\mathrm{HCV}$, when available, are having large effects on survival and quality of life and have opened new avenues for effective prevention [19-22]. Evidence on intervention best practice is mounting and is increasingly based on larger and better designed studies [23, 24].

Drug policies have also started to shift, even if the translation of evidence into policy remains difficult [25-28]. In some countries, there is cooperation between judicial and health authorities to mitigate harms associated with the criminalisation of drug use [29] and explicit or de facto decriminalisation of drug use [30-32] - these may often go together [33] —or even legalisation, in the case of cannabis [34-37]. Human rights-based approaches to drug treatment, incorporating harm reduction and social integration, have been implemented in a number of countries despite universal, national and global drug prohibition policies [38-40]. Despite such positive progress, however, many countries still have very low implementation levels of evidence-based programmes, exposing PWUD and the wider society to unnecessary health risks $[13,15,41]$. Above all, interventions appear to be frequently lacking for some of the most socially deprived groups, such as homeless, migrants, sex workers and prisoners [42-52]. Harm reduction and drug policy more widely have not been high on the international political agenda, with the United Nations General Assembly
Special Session on the World Drug Problem in 2016 being the first high-level meeting after many years with the aim to debate drug policy. Also, the global target to reduce new HIV infections by $50 \%$ by 2015 was missed, and the latest UNAIDS (The Joint United Nations Programme on HIV/AIDS) report suggests that HIV infections among this group actually increased by one third between 2011 and 2015 [53].

Critically, there are still continuous gaps in information on how effectively interventions are actually being provided; their coverage, quality, client characteristics and the degree to which they fulfil the needs of different populations of drug users [13, 15, 54-56]. While in many countries there are regular-often costly-epidemiological studies on the characteristics and behaviours of drug users, the collection of comparable and reliable monitoring data on the extent and quality of routine interventions (for example NSP) and service implementation remains rare. Epidemiological studies and routine analysis of health indicator data are key to evaluating drug service effectiveness, but they are infrequently extended to and combined with detailed information on intervention characteristics $[15,41,57-59]$. A tight nexus between indicators of quality and drug service provision and health outcomes has been documented [60-62]. Despite the wide range of quality standards and best practice guidelines for drug services on the national and international level $[6,23,24,56]$, research has shown that adherence to these guidelines should not be taken for granted, and there is a need for data that reflect the reality of actual practice 'on the ground' $[63,64]$. There is increasing interest in the quality and coverage of harm reduction services for people who use drugs and in the development of methodologies for measuring these $[6,56,65]$. An understanding of what services are being provided, in what form and the extent to which they are provided to individual users, including their views on the provision (where possible extending to enumeration of costs and if possible-in separate studies by specialist researchers-modelling of cost-effectiveness) is critical to the analysis of public health needs and whether these are adequately addressed.

This paper aims to identify which standardised data are needed-and why-for monitoring both the coverage and quality of harm reduction services [56]. This is not the type of research question that can be readily addressed through standard epidemiological methods. Rather, useful 
approaches may include analysis of historical developments in the area, critical discussion of current best practices (i.e. indicators in use that have proved successful) and data gap analysis.

\section{Methods}

As a first step, we describe the historical development of established international monitoring systems and indicators in the field of drugs and health. We then propose a framework for further indicator development and evaluation in the area of harm reduction (and potentially other drug services, for examples see the footnotes below Table 3). This framework was developed using consensus methods, including nominal group meetings and email discussions $[66,67]$ reviewing existing quality standards $[6,56,68]$, to capture and analyse the opinion and experience from a broad range of professionals/experts. The participating experts provided different perspectives and expertise (international and national monitoring system specialists, researchers, harm reduction professionals, government representatives) and included members of civil society organisations representing PWUD and people living with $\mathrm{HIV} / \mathrm{HCV}$. The framework lists candidate indicators for OAT, NSP and generic cross-cutting indicators for harm reduction (and potentially other drug) services. The framework with candidate indicators was developed in an iterative process of multiple commenting rounds until a stable consensus list of potential indicators (and areas for future indicator development) emerged. We discuss constraints (e.g. funding, ideology) and conditions for potential successful development of the suggested candidate indicators.

\section{Results}

\section{Historical development of existing drug use monitoring} systems

The global development of indicators in the drugs field was spearheaded in the area of HIV/AIDS. In 1989, one of the first common sets of indicators (behavioural) for people who inject drugs (PWID) was applied across countries by the World Health Organization (WHO) '13 cities study of drug injecting and HIV infection' [69]. In 1998, the National Institute on Drug Abuse (NIDA), WHO and UNAIDS formed the 'Global Research Network on HIV Prevention in Drug-Using Populations' (GRN) to help control the HIV epidemic among PWID [70] by discussing best practice and exchanging national study methods and results in international meetings. The GRN was succeeded in 2004 by the 'Reference Group to the United Nations on HIV and Injecting Drug Use', a network funded by UNODC, WHO and UNAIDS, to estimate the global spread of HIV among PWID [71-73] and intervention coverage [13] using common methodology, which culminated in UN guidance for countries to set targets for intervention coverage [6,74] and implementation [75]. Ongoing global monitoring has more recently been taken up by UN reporting systems [76, 77] and nongovernmental and academic organisations [2, 78].

In Europe, comparable work on drug use started in 1982 with the 'Multi-city study of drug misuse in Europe' [79]. This expert network developed epidemiological indicators to interpret trends in drug use and their consequences from routine sources and studies across countries, leading to the first pan-European drug treatment data monitoring protocol $[80,81]$. European multi-country impact studies on HIV/AIDS and PWID followed in 1989-1993 [82-87], leading to an increased interest in preventing HIV transmission in prisons [88-90]. The growing global attention paid to HIV/AIDS accelerated the urgency to improve responses for PWID, leading to the creation of a single agency for the European Union (EU) in the area of drugs. Since 1995, the European Monitoring Centre for Drugs and Drug Addiction (EMCDDA) and its national partners (the 'Reitox Network' (Réseau Européen d Information sur les Drogues et les Toxicomanies) of National Focal Points, as well as multiple topic-specific expert networks, have collaborated to gather evidence on the situation of drugs and their consequences to support national policymaking [41, 91-97]. A central area of this work concerns the development of the five 'key epidemiological indicators' of drug use and its consequences (general population surveys, population size estimates of PWUD at high risk of (or already experiencing) negative consequences and that include hidden populations, infectious diseases-HIV and viral hepatitis, overdose deaths, treatment demand) (Table 1) [98-100]. Despite the difficulties of collecting reliable data at a pan-European level, [101-103] these are being relatively well reported (almost all countries reporting on most indicators, Table 1), and they have been followed at the global level [73, 104-106].

A smaller number of intervention indicators were also developed, in the areas of drug treatment and harm reduction (Table 2). These concern both the provision of services (counts of clients entering treatment or syringes and clients/contacts in NSP) as well as coverage indicators (provision divided by estimates of the population in need of the service) [15, 107-109]. In 2013, a majority of countries were able to provide most of the provision indicators. However, reporting of the coverage indicators was significantly weaker, mainly because they necessitate additional information, in the form of population size estimates for PWUD as their denominators (from Table 1) (Table 2). Although provision indicators are important, for example to follow trends over time, they have inherent limitations, and additional coverage indicators are essential.

Rates of drug use or drug injection differ strongly between countries, and thus, the comparability and 
Table 1 Epidemiological indicators for people who use drugs being used at European Union level

\begin{tabular}{|c|c|c|c|c|}
\hline Domain & Indicators & $\begin{array}{l}\text { Countries, out of } 30 \text {, } \\
\text { reporting in } 2011- \\
2015^{\text {b }}\end{array}$ & $\begin{array}{l}\text { Data } \\
\text { type }\end{array}$ & Additional information \\
\hline $\begin{array}{l}\text { Prevalence of drug } \\
\text { use in the general } \\
\text { population }\end{array}$ & $\begin{array}{l}\text { Prevalence of lifetime use, last } \\
\text { year use, last month use }\end{array}$ & 25 & $\%$ & $\begin{array}{l}\text { Representative (household) surveys with breakdowns by } \\
\text { drug, age, gender, complemented by school surveys in } \\
15-16 \text { year old students (ESPAD) http://www.espad.org/ }\end{array}$ \\
\hline $\begin{array}{l}\text { High-risk drug use/ } \\
\text { problem drug use } \mathrm{e}^{\mathrm{a}, \mathrm{c}}\end{array}$ & $\begin{array}{l}\text { Population size estimates of } \\
\text { high-risk PWUD including } \\
\text { hidden populations (all, } \\
\text { opioids, stimulants, PWID) }\end{array}$ & 25 & $\begin{array}{l}\text { Rate/ } \\
1000\end{array}$ & Confidence intervals, estimation methods \\
\hline Treatment demand ${ }^{a}$ & Clients entering treatment & 30 & Counts & $\begin{array}{l}\text { Breakdowns by ever previously treated, } \\
\text { treatment type, prison, main drug, sex, } \\
\text { age at treatment, age at first use, referral } \\
\text { source, living status, education, labour status, } \\
\text { route of administration, frequency of use }\end{array}$ \\
\hline Overdose deaths $^{a}$ & Number of deaths, average age & 30 & Counts & Breakdowns by gender, toxicology, ICD code \\
\hline Infectious diseases $^{\mathrm{a}}$ & $\begin{array}{l}\text { Notifications and prevalence of } \\
\text { HIV/AIDS, HBV, HCV among PWID }\end{array}$ & $\begin{array}{l}\text { Prevalence: HIV } 29 \\
\text { HCV } 25 \text {, HBV 18-16; } \\
\text { notifications: HIV/AIDS } \\
30 / 29\end{array}$ & $\begin{array}{l}\text { Counts, } \\
\%\end{array}$ & Prevalence among young and new PWID \\
\hline Seizures of drugs & Number, quantity in kg & 28,30 & $\begin{array}{l}\text { Counts, } \\
\text { weights }\end{array}$ & Seizures by drug class, cannabis plants, tablets/doses \\
\hline $\begin{array}{l}\text { Price, purity/ } \\
\text { potency }\end{array}$ & Price, potency/purity & 29,29 & $\begin{array}{l}\text { Euro/g, } \\
\% \\
(\% \mathrm{THC})^{\mathrm{e}}\end{array}$ & $\begin{array}{l}\text { Sample size, summary statistics, composition (\% } \\
\mathrm{MDMA}^{\mathrm{d}} / \text { (meth)amphetamines) }\end{array}$ \\
\hline Drug use in prison & $\begin{array}{l}\text { Prevalence of lifetime use, } \\
\text { last year use, last month use }\end{array}$ & 10 & $\%$ & Breakdowns by: before/in prison, drug class \\
\hline Drug law offences & $\begin{array}{l}\text { Number of: offences, offenders, } \\
\text { either }\end{array}$ & $25,21,30$ & Counts & Breakdowns by type (use, supply), drug class \\
\hline
\end{tabular}

${ }^{a}$ Five 'key epidemiological indicators'. Available at http://www.emcdda.europa.eu/data/stats2016

${ }^{b}$ Year of reporting data to EMCDDA-the actual study year (year of primary data collection) is mostly 1 year earlier

'This key indicator has been renamed from 'Problem Drug Use' (definition: 'injecting drug use or long duration/regular use of opiates, cocaine and/or

amphetamines') to 'High Risk Drug Use' (definition: 'recurrent drug use that is causing actual harms (negative consequences) to the person (including dependence

but also other health, psychological or social problems), or is placing the person at a high probability/risk of suffering such harms'). It attempts to define and estimate the population size of those PWUD that are likely to be in need of services due to having (a high risk of) negative consequences from their drug use, such as PWID or people who use opioids

d 3,4-Methylenedioxymethamphetamine ('ecstasy')

'Tetrahydrocannabinol

Table 2 Health and social intervention indicators for people who use opioids and people who inject drugs being used at European Union level

\begin{tabular}{|c|c|c|c|c|}
\hline Intervention & Indicators & $\begin{array}{l}\text { Countries, out of } 30, \\
\text { reporting in } 2011-2015^{a}\end{array}$ & Data type & Additional information \\
\hline \multicolumn{5}{|l|}{ Provision } \\
\hline Drug treatment (total) & All clients & 30 & Counts & - \\
\hline OAT & All clients, by OAT medication & 30,30 & Counts & Legal framework/providers \\
\hline NSP & $\begin{array}{l}\text { Syringes provided, clients, contacts, fixed sites, } \\
\text { outreach sites }\end{array}$ & $25,19,20,28,26$ & Counts & $\begin{array}{l}\text { Estimated reporting coverage } \\
(\%), \text { NUTS2/3 level }{ }^{b}\end{array}$ \\
\hline \multicolumn{5}{|l|}{ Coverage } \\
\hline OAT & $\begin{array}{l}\text { OAT clients divided by the estimated number } \\
\text { of opioid users (Fig. 1) }\end{array}$ & 20 & $\%$ & $\begin{array}{l}\text { Confidence intervals, estimation } \\
\text { methods }\end{array}$ \\
\hline NSP & $\begin{array}{l}\text { Syringes provided divided by the estimated } \\
\text { number of PWID (Fig. 2) }\end{array}$ & 14 & $\%$ & $\begin{array}{l}\text { Confidence intervals, estimation } \\
\text { methods }\end{array}$ \\
\hline
\end{tabular}

Available at http://www.emcdda.europa.eu/data/stats2016

${ }^{a}$ Year of reporting data to EMCDDA-the actual study year (year of primary data collection) is mostly 1 year earlier

${ }^{\mathrm{b}}$ Nomenclature of Territorial Units for Statistics 
interpretability of the simpler provision indicators (as counts, or rates per general population) may be seriously compromised with regard to the target populations of people who use opioids or PWID. Nevertheless, coverage indicators clearly also have limitations, for example uncertainty intervals around central estimates are often large and estimation methods not uniform, in addition to the lower reporting rates [41].

However, despite the significant drawbacks, they provide relatively comparable evidence ('best available estimates') across countries with regard to whether services meet the needs of the target population, with recent data suggesting that important differences in coverage may exist between countries in Europe (Figs. 1 and 2). These coverage indicators have been adopted at global level to assess policy implementation in the drug field $[6,13,41$, 74]. At the same time, it is clear that they are limited in terms of giving insight into modalities of provision and the perspectives of people using the service; thus, developing additional indicators of service quality is likely to improve the usefulness and interpretability of the intervention coverage indicators. Existing quality standards $[6,56,68]$ provide an important basis for developing epidemiological indicators of service quality.

\section{Results of the expert group consultation}

During 2014 and 2015, an international expert network began discussions to advance the monitoring and evaluation of best practice in drug-related interventions in
Europe. It recommended focusing on the monitoring of coverage and quality of harm reduction services, as a first step to improving best practice implementation of wider drug services. This could best be achieved by integrating a limited set of additional indicators into the existing intervention indicators as currently coordinated by the EMCDDA as well as strengthening the reporting of existing indicators. Any additional indicators would then benefit from the ongoing efforts by European countries to ensure the timeliness, quality and completeness of data. Candidate indicators should compare key aspects of intervention delivery across countries, should be relatively easy to collect, where possible be evidence-based and, if not, based on expert consensus, and represent quality and coverage of services [110]. It was decided to start in a pragmatic way by producing a 'framework', i.e. mapping a list of potentially suitable candidate indicators and areas for future indicators, building on existing quality standards $[6,56,68]$, the available expert opinions and experience and using consensus methods, as described above. The candidate indicators were chosen on their potential to reflect the structural and procedural quality of harm reduction services and service coverage $[6,56]$. In future work, similar indicators could be set up for other interventions for PWUD, e.g. antiviral therapy or infectious disease testing $[5,6,111]$. For the suggested framework with candidate indicators of harm reduction service quality and coverage (OAT, NSP and generic cross-cutting' indicators), see Table 3.

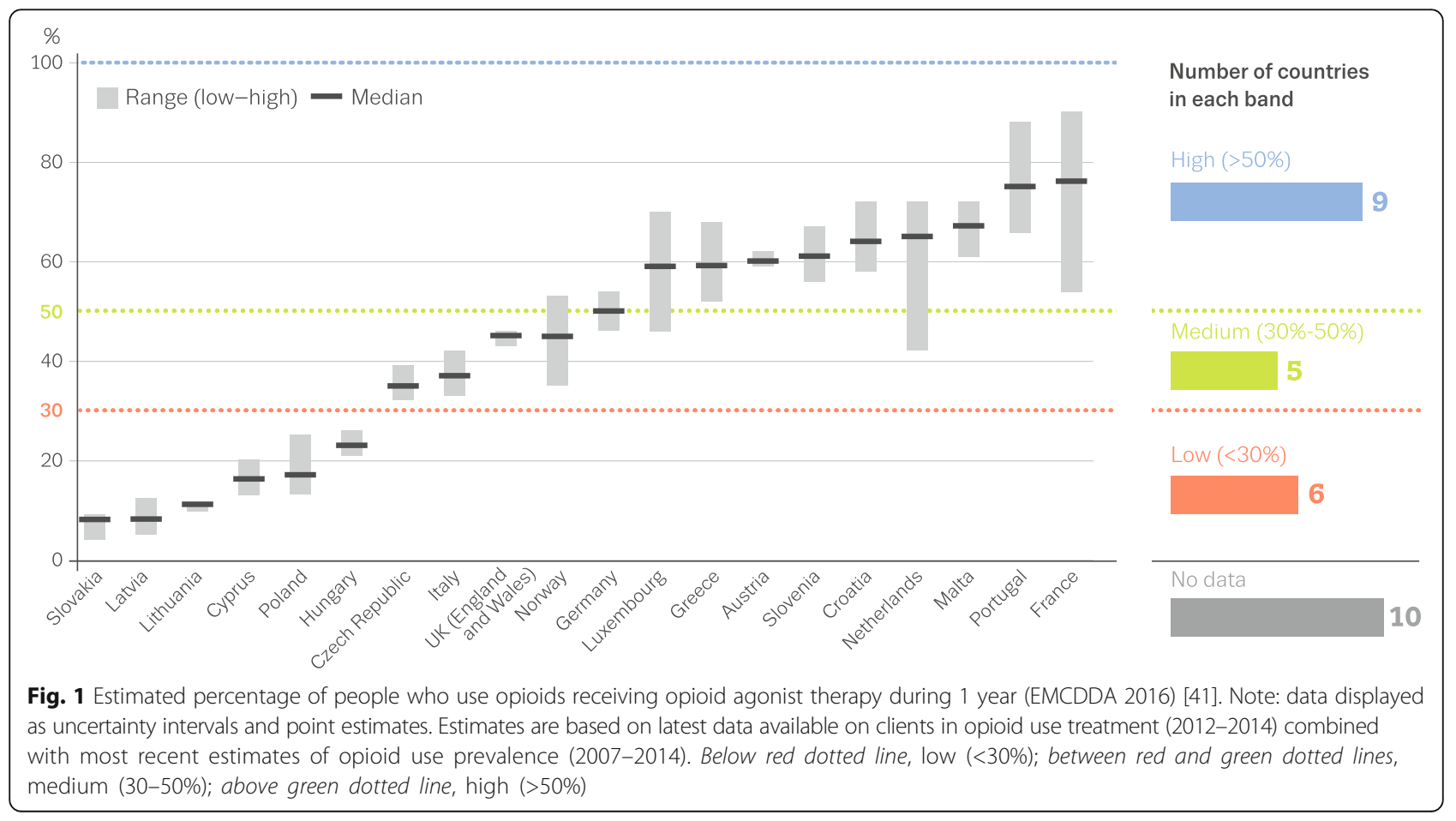




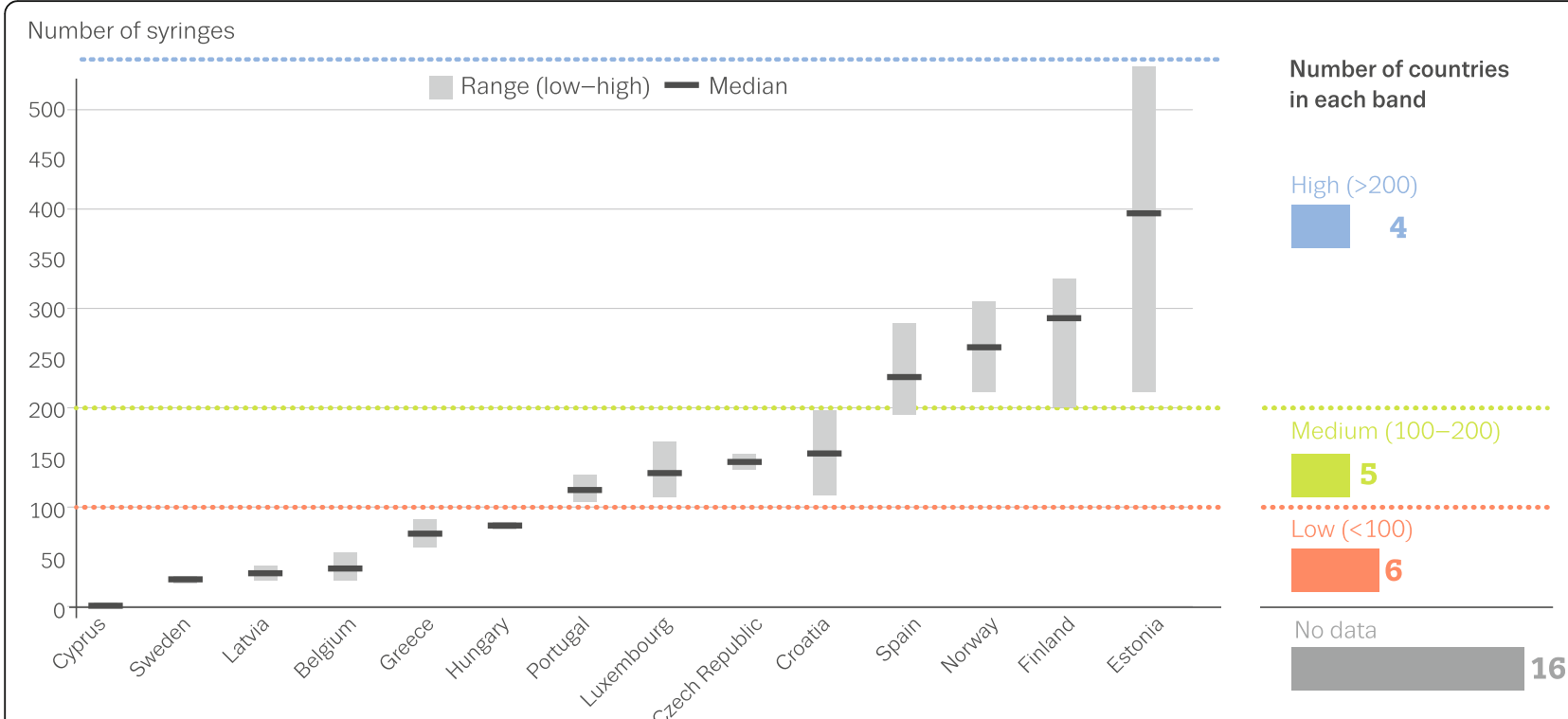

Fig. 2 Estimated number of syringes provided annually through specialised programmes per person who injects drugs (EMCDDA 2016) [41]. Note: data displayed as uncertainty intervals and point estimates. Estimates are based on latest data available on syringe provision (2013-2014) combined with most recent estimates of PWID prevalence (2008-2014). Below red dotted line, low $(<100)$; between red and green dotted lines, medium (100-200); above green dotted line, high (>200).

\section{Framework of potential indicators and areas for consideration}

As expected, two main interventions were indicated by the experts as central to harm reduction (mainly, prevention of infectious diseases such as HIV and viral hepatitis and of opiate-related overdose), namely, NSP and OAT. Other areas in harm reduction for further consideration of indicator development, but for practical reasons not included among the recommended indicators, included ART (both for HIV and viral hepatitis), consumption rooms and heroin-assisted treatment (Table 3). Under the specific OAT indicators, priority indicators included 'coverage', 'waiting list time', 'dosage' and 'availability in prisons'. For the specific NSP indicators, the priority indicators included 'coverage', 'number of needles/syringes distributed/collected', 'provision of other drug use paraphernalia' and 'availability in prisons'. Among the generic or cross-cutting indicators proposed for harm reduction services (and potentially other drug services), the priority indicators were 'infectious diseases counselling and care', 'take home naloxone', 'information on safe use/sex' and 'condoms' (for details, see Table 3).

\section{Discussion}

This consensus study provides a basis for the development and implementation of indicators of harm reduction quality and coverage and highlights further areas of potential monitoring of best practice intervention. Twelve priority candidate indicators were identified, on OAT, NSP and generic service quality aspects. Most of these seem relatively easy to monitor, consisting of simple 'yes/no' responses or a basic statistic. We propose conducting a pilot study to test the feasibility and applicability of the proposed indicators before their scaling up, to evaluate their effectiveness in comparing service quality across countries. From the experience in Europe, we suggest that this development should be collaborative ('bottom-up') making use of national and local experience and involving a broad range of experts and stakeholders (e.g. professionals, policymakers, representatives of people who use drugs and/or drug services, harm reduction organisations) across countries [56].

Important services were not included for monitoring, e.g. ART, mainly due to difficulties in finding a simple operationalisation or a key statistic from routine data that is readily available for all countries to be reported (such data may be obtained by special surveys; however, these are costly). While NSP and OAT are services that are specific for people who use opioids or PWID, respectively, and thus client numbers can be interpreted more easily, for ART this is not the case and in practice it is harder to come by reliable numbers for specific atrisk groups in treatment, e.g. PWID or men who have sex with men. Other services that are important but were not included are heroin-assisted treatment, drug consumption rooms/safer injection facilities, drug testing and water provision at rave parties, police interactions with drug users and interventions in special settings such as prisons. Again, their non-inclusion resulted not because they were considered unimportant but rather 
Table 3 Framework for the development of indicators for quality monitoring of harm reduction services, with a focus on opioid agonist therapy (OAT) and needle and syringe programmes (NSP); priority indicators are in italics

Specific OAT indicators may include ${ }^{a}$ :

Coverage of estimated opioid user population (\%, see Fig. 1)

Waiting time to first treatment admission (months)

\section{Methadone/buprenorphine dosage (grams)}

OAT available (including new initiation) in prisons (in all /in some /no)

OAT medicine covered by state /health insurance (yes /partly /no)

Illicit drug consumption tolerated (after dose induction phase) (yes /no)

Diagnosis or detailed assessment of current substance use, individualised treatment planning (yes /no)

Take home OAT available (yes /no)

Counselling required (yes /no)

Specific NSP indicators may include ${ }^{a}$ :

Coverage of estimated PWID population (syringes /PWID /year, see Fig. 2)

Annual number of needles/syringes distributed and collected (administrative data, and /or estimated by weight $)^{b}$

Provision of drug use equipment and injecting paraphernalia (including for non-injected use e.g. foils for heroin chasing, stems and filters for crack smoking) (in all /in some /no)

NSP available in prisons (in all /in some /no)

Coverage of all undertaken injections (syringes /100 injections)

Restrictions in numbers of syringes distributed per contact (yes /no)

Type of syringes (\% low dead space, acceptance by users)

Modality (specialised NSP, outreach, pharmacy, other, e.g. drug treatment service)

Brief opportunistic motivational interventions provided (yes /no)

Generic cross-cutting indicators for harm reduction (and other drug services) may includea:

Infectious diseases counselling, testing, vaccination and referrals (e.g. $H I V, H C V, H B V, T B$ ) (in all /in some /no)

Take away naloxone provided (in all /in some /no)

Information provided on safer use, injecting and safer sex (in all /in some/no)

Condoms provided (in all /in some /no)

Accessibility: opening times and geographic coverage, outreach activities, costs to clients, no age limits, no parental consent requirements, targeted programmes for special populations (e.g. (pregnant) women, sex workers, underage users) (to construct overall index score: high /medium /low)

Integration /cooperation with other services and continuity of care: e.g. shared location /referrals to NSP, OAT, infectious diseases counselling and testing, antiviral and other medical treatment and care, overdose prevention, social support, housing, education, employment services (in all /in some /no)

Regular consultation with law enforcement /community /neighbourhood: avoiding nuisance and conflict, improving safety for both clients and community (index: high /medium /low)

Regular consultation with the users of the service: feedback, evaluation, client satisfaction (index: high /medium /low)
Table 3 (Continued)

Assessment procedures: risk behaviours, needs, health status, informed consent, data confidentiality, written client records (index: high /medium /low)

Psycho-social interventions provided (with or without medication) (yes /no)

Frequency of contact with a counsellor /social worker (times per month)

Staff qualification, multidisciplinarity, education and (ongoing) training (index: high /medium /low)

Case /contact management follows protocol /guidelines (yes /no, specify which)

Type of funding source: private /public; national /international, etc.; and security of funding (per client, grant-based, etc.), utilisation monitoring (treatment slots used), peer support /aid (to construct an overall index score on funding continuity and reliability: high /medium /low)

aThe quality indicators listed are mostly structural and procedural [56]. Outcome indicators are limited to OAT and NSP coverage estimates. Other outcome indicators may be considered (e.g. client retention and return rates, reductions in drug use, crime, improvements in health, etc.), but given their complexity, this may be more appropriate to assess in detailed service evaluation studies at national or local level [171] (although note [110]). Further work may be needed to link up more strongly with recently adopted EU quality standards [68]. Other harm reduction and drug interventions to be considered for monitoring may include antiviral and antibacterial therapy (e.g. HIV, HCV, HBV, TB), heroin-assisted treatment, drug consumption rooms/safer injecting facilities, testing drug content and handing out water at rave parties and similar events, police interactions with drug users affecting service utilisation, interventions in special settings (e.g. prisons, mobile or outreach interventions), social interventions, e.g. relating to children or family of PWUD, and monitoring and may even extend to drug policy indicators (e.g. minimum quantities of drugs allowed for personal use, sentencing practise, medical use of cannabis, decriminalisation/liberalisation of drug laws, drug treatment regulations, e.g. allowing opioid agonist therapy through primary caregivers), continuity of care following prison release or treatment discharge ${ }^{b}$ Measuring infection rates in returned syringes may form an important and cost-effective method for monitoring prevalence and incidence of infection in the population $[135,136]$.

Measures of central tendency (e.g. mean, median) may be complemented by measures of variability (e.g. range, interquartile range) to better capture intra- and inter-national variation.

they were thought to be harder to monitor (e.g. police interactions) or to be partly overlapping with other indicators (e.g. safer injection rooms with NSP). However, indicators not included here might still be considered for implementation by individual countries depending on national context and priorities. For example, in many Latin American and Caribbean countries, stimulant use is more important than opioids, which might require adapting the indicators $[2,112]$. Our approach might be extended to areas surrounding the actual implementation of drug services. For example, drug policy indicators could be considered for monitoring, e.g. sentencing practices and minimum quantities of drugs allowed for personal use, decriminalisation/liberalisation of drug laws or drug treatment regulations may have profound impact on health and well-being of PWUD. A recent study proposed a framework to classify countries by 
their models of 'governance of addictions' from an analysis of national drug strategies [33]. Monitoring both drug policies and their actual implementation and practice might reveal important discrepancies between the two, providing key policy relevant information $[113,114]$.

Indicators for the quality of drug services must be closely linked to epidemiological data and methods. The development of OAT and NSP coverage indicators (Figs. 1 and 2) was made possible by the increased availability of routine epidemiological monitoring data and the increased use of statistical modelling methods. The methods to estimate population sizes of PWUD/PWID originated in biology and continue to be improved for epidemiological application even if they have not essentially changed [97, 102, 105, 115-129]. Mathematical and statistical modelling has more generally been useful to improve our understanding of intervention effectiveness and cost-effectiveness as well as to give insight in potential epidemic courses and processes, thus providing some basis to evaluate interventions [95-97, 130-134]. Different types of intervention have been studied using mathematical models, such as impact of needle exchange programmes [135, 136], impact of behavioural changes [137] and impact of treatment on transmission [138, 139]. Recent studies suggest that molecular analyses of infectious diseases may also provide added value to epidemiological surveillance as a basis for evaluating interventions [48, 140-143]. Moreover, comprehensive reviews of epidemiological data (and intervention effectiveness and implementation) have been carried out to estimate the burden of disease and quality of life, providing a means to compare health and societal impact of interventions across different diseases including through cost-effectiveness analyses [144-148]. Indicators should not be limited to national-level data only. Having subnational breakdowns-by city or region-would be critical to understand within-country variation in epidemiological trends and intervention impact [149-152].

Apart from using the proposed indicators individually, they might be used for system-level evaluation to monitor and guide service integration and referral at national level. For example, it is important to use these indicators together to assess the comprehensiveness of harm reduction programming, given the evidence that harm reduction interventions are most effective when used in combination [138, 153]. Another example of a combined approach may be provided by a 'harm reduction cascade' model, similar to the recently proposed HIV or HCV care cascades [19, 154, 155], where the 'flow' of people who use drugs would be modelled through a tailored set of services, ranging from catering the needs of incidental or recreational users to those who inject drugs or are heavily dependent, and/or may have a range of health and social problems. The HIV and HCV cascade model enables the identification of gaps in health system performance by estimating the percentage of infected who know their status, percentage of those in care, percentage of those on ART and percentage of those with undetectable viral load/sustained virologic response. Care cascade indicators relate to the timely provision of ART for HIV and best medical practices for HBV, HCV and other diseases (endocarditis, methicillin-resistant staphylococcus aureus (MRSA), anthrax, TB, etc.) and might similarly be developed for drug prevention, treatment and harm reduction measures. Another example focuses on the interface between judicial and public health interventions. This includes the analysis of police interactions with drug users in the context of their service utilisation, policy indicators (e.g. minimum quantities of drugs allowed for personal use, sentencing practice, medical use of cannabis, decriminalisation/liberalisation of drug laws [37]) and the continuity of care following prison release $[156,157]$.

The feasibility of monitoring drug service implementation will depend on resources in countries and may therefore be more limited in low and middle income countries. However, where a country lacks the resources to implement and further develop these indicators, the proposed framework may be useful to document the absence of data in specific areas, even if in a rudimentary form (e.g. a binary 'yes/no' checklist). Monitoring performance should be evaluated only after several years of data collection using performance indicators such as the number of countries providing data and assessments of the credibility of the methods and sources behind the available data. In practice it may take many years to arrive at a high reporting rate with good quality data, and maintaining a long-term perspective is necessary. With respect to clinical services performance, which is evaluated by health insurance systems and/or national health authorities [158], monitoring drug services may pose specific difficulties due to their multi-disciplinary nature and as they may depend on different government and private entities and multiple funding sources. Service provision may thus depend on the type of service providers (public, private, nongovernmental organizations including peer-driven initiatives, general medical practitioners), funding sources (central government, local and regional governments, social health insurance, private and other sources) and funding mechanisms (grants, treatment case, daily costs, fee for service or payment by result) [159]. Other aspects of funding might also impact on service performance, quality and outcomes-such as the way providers are chosen and the ways services are paid for, e.g. block grant, capitation, payment for activity or payment for outcome [160], although the evidence of how the funding provisions influence outcomes is mixed [161-163]. Additionally, disaggregated spending records could indicate whether programmes invest in 
adequate numbers of well-trained staff and procure quality commodities that meet the needs of the people accessing the service-all related to the quality of service provision. While we recommend monitoring harm reduction funding, this did not make it into the 12 priority indicators, as our focus has been on the service coverage and quality per se. While investment in itself would not denote quality, whether a programme is funded by government or an international donor can have implications for its sustainability that are important to monitor. There are several countries in Europe, as well as globally, facing issues with harm reduction sustainability and funding. It would be timely to consider a separate pilot study on the use of indicators relating to harm reduction spending.

There are several limitations to this analysis. While we were able to identify a set of priority candidate indicators using a consensus approach, we cannot at this stage present empirical evidence on the potential problems or advantages associated with implementation of these indicators. However, with the established, mostly epidemiological, indicators (Tables 1 and 2), this was a process of trial and error where a number of countries start jointly piloting such data collection using an agreed protocol, exchange experiences in regular working group meetings and improve quality and comparability of data collection practice, adjusting the protocol if necessary. A prior step could be to carry out specific literature reviews on each of the indicators; however, this was beyond the scope of our study. Also, we were unable to grade the information and suggestions obtained from our expert group by levels of evidence quality [164], again this was beyond the scope of our study, and given the broad area we cover would have not been feasible. If in a future step specific reviews are carried out on each indicator it would be important to attempt grading the evidence for each of them, although such evidence is likely to be scarce and in need of being generated. Our consensus approach was not a formal Delphi study and could as such be criticised. However, we did include various consensus methods (expert meetings, repeated email commenting rounds) $[66,67]$. We believe it is unlikely the results would have differed much depending on the exact consensus approach, given that all participants agreed with the final version of framework and indicators. We have also not been able to identify clear candidate indicators for monitoring patient values and preferences regarding harm reduction services, although further work might well be able to define such indicators, as has been already attempted in drug treatment research [165-170]. Finally, the services here discussed and for which we propose to develop indicators are 'services' in the form of programmes that are established by governments or private professional organisations and run for the benefit of 'society' or, at least putatively, in the benefit of clients or patients. In organisational terms, these are top-down services. What is not discussed in this article is the array of self-financed or funded users' groups and their activities both in helping each other and also in providing useful and needed critique of the top-down services and policies. There is clearly a need for further work on this area with strong involvement of the target populations and their organisational representatives that services are serving.

\section{Conclusions}

We propose a framework for the further development of indicators of coverage and quality of harm reduction services, as a first step to improving best practice implementation in the drug field. This is based on the successful development of established monitoring systems and indicators, and an international consensus exercise. This framework might be especially of use for professionals in charge of monitoring and/or funding service implementation and quality at higher (e.g. national, international) levels of aggregation, in addition to providing some guidance at the local and individual service levels. From the framework, 12 priority candidate indicators emerge that are conceptually simple, likely suitable to be collected on a routine basis, and should provide comparable key evidence on the quality and coverage of opioid agonist therapy, needle and syringe programmes and generic drug service aspects. We propose conducting a pilot study to test the feasibility and applicability of the proposed indicators before their scaling up and routine implementation, to evaluate their effectiveness in comparing service quality across countries. The implementation of a limited set of validated and internationally agreed indicators for monitoring harm reduction service best practice will provide a stronger basis for future public health and epidemiological studies, in order to advance evidence-based health policy.

\section{Abbreviations}

ART: Antiretroviral therapy; DAA: Direct-acting antivirals; EMCDDA: European Monitoring Centre for Drugs and Drug Addiction; EU: European Union; GRN: Global Research Network; HBV: Hepatitis B virus; HCV: Hepatitis C virus; HIV: Human immunodeficiency virus; MDMA: 3,4Methylenedioxymethamphetamine (ecstasy); MRSA: Methicillin-resistant staphylococcus aureus; NIDA: National Institute on Drug Abuse; NSP: Needle and syringe programmes; NUTS: Nomenclature of Territorial Units for Statistics; OAT: Opioid agonist therapy; PWID: People who inject drugs; PWUD: People who use drugs; Reitox: Réseau Européen

d'Information sur les Drogues et les Toxicomanies; TB: Tuberculosis: THC: Tetrahydrocannabinol; UNAIDS: The Joint United Nations Programme on HIV/AIDS; WHO: World Health Organization

\section{Acknowledgements}

The authors would like to acknowledge the additional collaborators in the EUBEST working group: Sabrina Molinaro, Michela Franchini, Valeria Siciliano, Elisa Benedetti (Institute of Clinical Physiology (CNR), Pisa, Italy); Marco Perduca (Associazione Luca Coscioni, Rome, Italy); Alban Ylli (Foundation Our Lady of Good Counsel-Catholic University Our Lady of Good Counsel, Tirana, Albania); Gregorio Barrio Anta (National School of Public Health; Carlos III Health Institute; Addictive Disorders Network (RTA); Madrid, Spain); Maria José Bravo Portela (National Centre of Epidemiology; Carlos III Health Institute; Consortium for Biomedical Research in Epidemiology and Public 
Health (CIBERESP); Madrid, Spain), Iciar Indave (National Centre of Epidemiology, Carlos III Health Institute, Madrid, Spain); József Rácz (Ë̈tvös Loránd University, Institute of Psychology; Semmelweis University, Faculty of Health Sciences; Blue Point Drug Counselling and Outpatient Centre; Budapest, Hungary); Tomáš Zábranský (Department of Addictology, First Faculty of Medicine, Charles University and General University Hospital; ResAd-Research and Development; AdRes Institute; Prague, Czech Republic); Michaela Štefunková (Institute of Criminology and Social Prevention; AdRes Institute; Prague, Czech Republic); Percy Fernandez Dávila (Stop Sida, Barcelona, Spain); Maris Salekesin, Sigrid Vorobjov (National institute for health development, Infectious Diseases and Drug Monitoring Department, Tallinn, Estonia); Monica Dan, Cristina Fierbinteanu, Dan Popescu, Ludmila Verdes (ARAS - the Romanian Association Against AIDS, Bucharest, Romania); Adrian-Octavian Abagiu (National Institute for Infectious Diseases Prof. Dr. Matei Bals, Department for OMT-ARENA); Angelos Hatzakis (Dept. of Hygiene, Epidemiology and Medical Statistics, National and Kapodistrian University of Athens, Athens, Greece); Maria Moudatsou, Tzanetos Antypas (NGO Praksis, Athens, Greece); Agnes Cadet-Tairou (French Monitoring Centre for Drugs and Drug Addiction (OFDT), Saint-Denis, France); Anne Marie Collins (Consultant, Barcelona, Spain); David Liddell (Scottish Drug Forum, Glasgow, UK).

\section{Funding}

Viktor Mravčík was supported by the institutional support no. PRVOUK-P03/ LF1/9 and the Project Nr. LO1611 with a financial support from the Czech Ministry of Youth and Sport under the NPU I program. Sam Friedman was supported by the National Institute on Drug Abuse Grants R01 DA13336 (Community Vulnerability and Response to IDU-Related HIV); DP1 DA034989 (HIV Transmission by Recently-Infected Drug Users); and P30 DA11041 (Center for Drug Use and HIV Research). Ana Sarasa-Renedo, Jeffrey V. Lazarus and Viktor Mravčík were supported by the joint action '677085/HA-REACT' ('The Joint Action on HIV and Co-infection Prevention and Harm Reduction'), which has received funding from the European Union's Health Programme (2014-2020)

\section{Availability of data and materials}

Data and material are available from the EMCDDA.

\section{Authors' contributions}

LW, MF, CC and CR conceived the paper. LW wrote all the versions. Al co-authors provided comments on the draft and final versions and approved the final version.

\section{Competing interests}

The authors declare that they have no competing interests.

\section{Consent for publication}

Not applicable.

\section{Ethics approval and consent to participate}

Not applicable.

\section{Publisher's Note}

Springer Nature remains neutral with regard to jurisdictional claims in published maps and institutional affiliations.

\section{Author details}

'European Monitoring Centre for Drugs and Drug Addiction (EMCDDA), Praça Europa 1, Cais do Sodré, 1249-289 Lisbon, Portugal. ${ }^{2}$ Department of Addictology, First Faculty of Medicine, Charles University and General University Hospital, Prague, Czech Republic. ${ }^{3}$ National Institute for Mental Health, Prague, Czech Republic. ${ }^{4}$ Uniting Medically Supervised Injecting Centre, Sydney, Australia. ${ }^{5}$ Marseille Univ, INSERM, IRD, SESSTIM, Marseille, France. ${ }^{6}$ ORS PACA, Marseille, France. ${ }^{7}$ Institute of Infectious Disease Research, National Development and Research Institutes, New York, USA. ${ }^{8}$ Centre d'Estudis Epidemiològics sobre les Infeccions de Transmissió Sexual i Sida de Catalunya (CEEISCAT), Agència de Salut Pública de Catalunya (ASPC), Barcelona, Spain. ${ }^{9}$ Consortium for Biomedical Research in Epidemiology and Public Health (CIBERESP), Madrid, Spain. ${ }^{10}$ Program of International Research and Training, National Drug and Alcohol Research Centre, The University of New South Wales (UNSW), Sydney, Australia. ${ }^{11}$ Health Research Board, Dublin, Ireland. ${ }^{12}$ School of Social and Community Medicine, University of Bristol,
Bristol, UK. ${ }^{13} \mathrm{CHIP}$, Rigshospitalet, University of Copenhagen, Copenhagen, Denmark. ${ }^{14}$ Barcelona Institute of Global Health (ISGlobal), Hospital Clinic, University of Barcelona, Barcelona, Spain. ${ }^{15}$ National Monitoring Centre for Drugs and Addiction, Prague, Czech Republic. ${ }^{16}$ Julius Center for Health Sciences and Primary Care, University Medical Center Utrecht, Utrecht, The Netherlands. ${ }^{17}$ Centre for Infectious Disease Control, National Institute for Public Health and the Environment, Bilthoven, The Netherlands.

${ }^{18}$ Department of Hygiene Epidemiology and Medical Statistics, Medical School, National and Kapodistrian University of Athens, Athens, Greece.

${ }^{19}$ Spanish Field Epidemiology Training Program (PEAC), National Centre of Epidemiology, Carlos III Health Institute, Madrid, Spain. ${ }^{20}$ Department of Family Medicine and Public Health, University of Tartu, Tartu, Estonia. ${ }^{21}$ Group of Activists on Treatments (GAT), Lisbon, Portugal. ${ }^{22}$ Intercambios Civil Association and University of Buenos Aires, Buenos Aires, Argentina. ${ }^{23}$ Alcohol, Drug, and Tobacco Division, Health and Wellbeing Directorate, Public Health England, London, UK. ${ }^{24}$ Leuven Institute of Criminology (LINC), Faculty of Law, University of Leuven, Leuven, Belgium. ${ }^{25}$ Centre for Global Governance Studies (GSS), Leuven, Belgium. ${ }^{26}$ French Monitoring Centre for Drugs and Drug Addiction (OFDT), Saint-Denis, France. ${ }^{27}$ The Romanian Association Against AIDS (ARAS), Bucharest, Romania. ${ }^{28}$ Department of Health, Wellington House, London, UK. ${ }^{29}$ Public Health Institute, Faculty of Education, Health and Community, Liverpool John Moores University, Liverpool, UK. ${ }^{30}$ Trinity College Dublin, The University of Dublin, Dublin, Ireland. ${ }^{31}$ Centro Studi Statistici e Sociali CE3S, Rome, Italy.

Received: 1 September 2016 Accepted: 4 March 2017 Published online: 22 April 2017

\section{References}

1. Samet JH, Fiellin DA. Opioid substitution therapy-time to replace the term. Lancet. 2015;385:1508-9.

2. Harm Reduction International. The global state of harm reduction 2016. Edited by Stone K. London: Harm Reduction International; 2016. https://www.hri. global/files/2016/11/14/GSHR2016_14nov.pdf. Accessed 20 Mar 2017.

3. Committee on the Prevention of HIV Infection among Injecting Drug Users in High-Risk Countries. Preventing HIV infection among injecting drug users in high risk countries: an assessment of the evidence. Washington: Institute of Medicine of the National Academies; 2006.

4. WHO. Evidence for action series - technical papers and policy briefs on HIV/ AIDS and injecting drug users. Geneva: WHO; 2015. http://www.who.int/hiv/ pub/idu/evidence_for_action/en/. Accessed 20 Mar 2017.

5. ECDC, EMCDDA. Prevention and control of infectious diseases among people who inject drugs. Stockholm: ECDC/EMCDDA; 2011. https://goo.gl/2rQBzv. Accessed 20 Mar 2017.

6. WHO, UNODC, UNAIDS. WHO, UNODC, UNAIDS technical guide for countries to set targets for universal access to HIV prevention, treatment and care for injecting drug users - 2012 revision. Geneva: WHO; 2012. http://apps.who.int/iris/ bitstream/10665/77969/1/9789241504379_eng.pdf?ua=1. Accessed 20 Mar 2017.

7. Palmateer NE, Taylor A, Goldberg DJ, Munro A, Aitken C, Shepherd SJ, et al. Rapid decline in HCV incidence among people who inject drugs associated with national scale-up in coverage of a combination of harm reduction interventions. PLoS ONE. 2014;9:e104515.

8. MacArthur GJ, van Velzen E, Palmateer N, Kimber J, Pharris A, Hope V, et al. Interventions to prevent HIV and hepatitis $C$ in people who inject drugs: a review of reviews to assess evidence of effectiveness. Int J Drug Policy. 2014;25:34-52.

9. Palmateer N, Kimber J, Hickman M, Hutchinson S, Rhodes T, Goldberg D. Evidence for the effectiveness of sterile injecting equipment provision in preventing hepatitis $C$ and human immunodeficiency virus transmission among injecting drug users: a review of reviews. Addiction. 2010;105:844-59.

10. Degenhardt L, Mathers BM, Wirtz AL, Wolfe D, Kamarulzaman A, Carrieri MP, et al. What has been achieved in HIV prevention, treatment and care for people who inject drugs, 2010-2012? A review of the six highest burden countries. Int J Drug Policy. 2014;25:53-60.

11. Aspinall EJ, Nambiar D, Goldberg DJ, Hickman M, Weir A, Van Velzen E, et al. Are needle and syringe programmes associated with a reduction in HIV transmission among people who inject drugs: a systematic review and meta-analysis. Int J Epidemiol. 2014;43:235-48.

12. Des Jarlais DC, Feelemyer JP, Modi SN, Abdul-Quader A, Hagan H. High coverage needle/syringe programs for people who inject drugs in low and middle income countries: a systematic review. BMC Public Health. 2013;13:53. 
13. Mathers BM, Degenhardt L, Ali H, Wiessing L, Hickman M, Mattick RP, et al. HIV prevention, treatment, and care services for people who inject drugs: a systematic review of global, regional, and national coverage. Lancet. 2010;375:1014-28.

14. Hedrich D, Pirona A, Wiessing L. From margin to mainstream: the evolution of harm reduction responses to problem drug use in Europe. Drugs Educ Prev Policy. 2008:15:503-17.

15. Wiessing L, Likatavicius G, Klempova D, Hedrich D, Nardone A, Griffiths P. Associations between availability and coverage of HIV-prevention measures and subsequent incidence of diagnosed HIV infection among injection drug users. Am J Public Health. 2009;99:1049-52. http://www.ncbi.nlm.nih.gov/ pmc/articles/PMC2679784/. Accessed 20 Mar 2017.

16. Strang J, Manning $V$, Mayet $S$, Titherington E, Offor $L$, Semmler $C$, et al. Family carers and the prevention of heroin overdose deaths: unmet training need and overlooked intervention opportunity of resuscitation training and supply of naloxone. Drugs Educ Prev Policy. 2008;15:211-8.

17. Williams AV, Strang J, Marsden J. Development of Opioid Overdose Knowledge (OOKS) and Attitudes (OOAS) Scales for take-home naloxone training evaluation. Drug Alcohol Depend. 2013;132:383-6.

18. Minozzi S, Amato L, Davoli M. Preventing fatal overdoses: a systematic review of the effectiveness of take-home naloxone. Office of the European Union: Luxembourg; 2015. http://www.emcdda.europa.eu/attachements. cfm/att_234376_EN_TDAU14009ENN.web_.pdf. Accessed 20 Mar 2017

19. Grebely J, Bruggmann P, Treloar C, Byrne J, Rhodes T, Dore GJ. Expanding access to prevention, care and treatment for hepatitis $C$ virus infection among people who inject drugs. Int J Drug Policy. 2015;26:893-8.

20. Mills EJ, Nachega JB, Bangsberg DR, Singh S, Rachlis B, Wu P, et al. Adherence to HAART: a systematic review of developed and developing nation patientreported barriers and facilitators. PLoS Med. 2006;3:e438.

21. Wood E, Milloy MJ, Montaner JS. HIV treatment as prevention among injection drug users. Curr Opin HIV AIDS. 2012;7:151-6.

22. Milloy MJ, Montaner J, Wood E. Barriers to HIV treatment among people who use injection drugs: implications for 'treatment as prevention'. Curr Opin HIV AIDS. 2012;7:332-8.

23. EMCDDA. Best practice portal. Lisbon: EMCDDA; 2017. http://www.emcdda. europa.eu/best-practice. Accessed 20 Mar 2017.

24. Ferri $\mathrm{M}, \mathrm{Bo} \mathrm{A}$. Best practice promotion in Europe: a web-based tool for the dissemination of evidence-based demand reduction interventions. Drugs Educ Prev Policy. 2013;20:331-7.

25. Maccoun RJ. The implicit rules of evidence-based policy analysis, updated. Addiction. 2010;105:1335-6.

26. MacCoun $R$, Reuter $P$. The implicit rules of evidence-based drug policy: a $U$. S. perspective. Int J Drug Policy. 2008;19:231-2.

27. Mravcik V. (De)criminalisation of possession of drugs for personal use-a view from the Czech Republic. Int J Drug Policy. 2015;26:705-7

28. Jolley E, Rhodes T, Platt L, Hope V, Latypov A, Donoghoe M et al. HIV among people who inject drugs in Central and Eastern Europe and Central Asia: a systematic review with implications for policy. BMJ Open. 2012;2:pii= e001465. http://bmjopen.bmj.com/content/bmjopen/2/5/e001465.full.pdf. Accessed 20 Mar 2017

29. Buster M, Dorn T, Ceelen M, Das K. Detainees in Amsterdam, a target population of the Public Mental Health System? J Forensic Leg Med. 2014:25:55-9.

30. Eastwood N, Fox E, Rosmarin A. A quiet revolution: drug decriminalisation across the globe. London: Release; 2016.

31. Goncalves R, Lourenco A, Silva SN. A social cost perspective in the wake of the Portuguese strategy for the fight against drugs. Int J Drug Policy. 2015;26:199-209.

32. Csete J. A balancing act: policymaking on illicit drugs in the Czech Republic. New York: Open Society Foundations; 2012. http://www.opensocietyfoundations.org/ sites/default/files/A_Balancing_Act-03-14-2012.pdf. Accessed 20 Mar 2017.

33. Ysa T, Colom J, Albareda A, Ramon A, Segura L. Governance of addictions: European public policies. Oxford: OUP; 2014

34. Hall W, Weier M. Assessing the public health impacts of legalizing recreational cannabis use in the USA. Clin Pharmacol Ther. 2015;97:607-15.

35. Wilkinson ST, Yarnell S, Radhakrishnan R, Ball SA, D'Souza DC. Marijuana legalization: impact on physicians and public health. Annu Rev Med. 2016; 67:453-66

36. Cressey D. The cannabis experiment. Nature. 2015;524:280-3.

37. Wiessing L, Des Jarlais D, Hughes B, Ferri M, Griffiths P. Cannabis: monitor policy changes. Nature. 2015;527:305.

38. Comiskey CM. We need to decriminalise small amounts of drugs and open safe heroin injecting centres. Int Bus Times. 2015. http://www.ibtimes.co.uk/ we-need-decriminalise-small-amounts-drugs-open-safe-heroin-injectingcentres-1527421. Accessed 20 Mar 2017.

39. Duncan DF, Nicholson T, White JB, Ellis-Griffith G. A brief history of prohibition and treatment solutions for substance abusers. Int J Criminol Sociol. 2014;3:186-99.

40. Levine HG. The secret of worldwide drug prohibition. Indep Rev. 2002;7: 165-80. http://www.independent.org/pdf/tir/tir_07_2_levine.pdf. Accessed 20 Mar 2017.

41. EMCDDA. European Drug Report 2016. Lisbon: EMCDDA; 2016. http://www. emcdda.europa.eu/system/files/publications/2637/TDAT16001ENN.pdf. Accessed 20 Mar 2017.

42. Strathdee SA, West BS, Reed E, Moazen B, Azim T, Dolan K. Substance use and HIV among female sex workers and female prisoners: risk environments and implications for prevention, treatment, and policies. J Acquir Immune Defic Syndr. 2015:69 Suppl 2:S110-7.

43. Larney S, Dolan K. A literature review of international implementation of opioid substitution treatment in prisons: equivalence of care? Eur Addict Res. 2009;15:107-12

44. Dolan K, Kite B, Black E, Aceijas C, Stimson GV. HIV in prison in low-income and middle-income countries. Lancet Infect Dis. 2007;7:32-41.

45. UNODC, ILO, UNDP, WHO, UNAIDS. Prevention, treatment and care in prisons and other closed settings: a comprehensive package of interventions. Vienna: United Nations Office on Drugs and Crime; 2013. https://www.unodc.org/documents/hiv-aids/HIV_comprehensive_package_ prison_2013_eBook.pdf. Accessed 20 Mar 2017.

46. Sypsa V, Paraskevis D, Malliori M, Nikolopoulos GK, Panopoulos A, Kantzanou $\mathrm{M}$, et al. Homelessness and Other Risk Factors for HIV Infection in the Current Outbreak Among Injection Drug Users in Athens, Greece. Am J Public Health. 2015;105:196-204.

47. Folch C, Casabona J, Espelt A, Majo X, Merono M, Gonzalez V, et al. High prevalence and incidence of HIV and HCV among new injecting drug users with a large proportion of migrants-is prevention failing? Subst Use Misuse. 2016;51:250-60.

48. Paraskevis D, Nikolopoulos G, Tsiara C, Paraskeva D, Antoniadou A, Lazanas M, et al. HIV-1 outbreak among injecting drug users in Greece, 2011: a preliminary report. Euro Surveill. 2011;16:pii=19962. http://www. eurosurveillance.org/NiewArticle.aspx?Articleld=19962. Accessed 20 Mar 2017.

49. Shannon K, Strathdee SA, Goldenberg SM, Duff P, Mwangi P, Rusakova M, et al. Global epidemiology of HIV among female sex workers: influence of structural determinants. Lancet. 2015;385:55-71.

50. Wiessing LG, van Roosmalen MS, Koedijk P, Bieleman B, Houweling H. Silicones, hormones and HIV in transgender street prostitutes. AIDS. 1999:13:2315-6.

51. Miri L, Wakrim L, Kassar H, Hemminki K, Khyatti M. Impact of immigration on HIV-1 molecular epidemiology in West Africa, Maghreb and Southern Europe. AIDS Rev. 2014;16:109-16.

52. Blondell SJ, Kitter B, Griffin MP, Durham J. Barriers and Facilitators to HIV Testing in Migrants in High-Income Countries: A Systematic Review. AIDS Behav. 2015;19:2012-24.

53. UNAIDS. Get on the fast-track - the life-cycle approach to HIV. Geneva: UNAIDS; 2016. http://www.unaids.org/sites/default/files/media_asset/Get-onthe-Fast-Track_en.pdf. Accessed 20 Mar 2017.

54. Ferri M, Bo A, Amato L, Correia Guedes I, Esteves CS, Wiessing L et al. What is needed in future drug treatment research? A systematic approach to identify gaps on effectiveness of drug treatment from the EMCDDA. Drugs Educ Prev Policy. 2014:22:86-92. http://www.tandfonline.com/doi/pdf/10. 3109/09687637.2014.954988?needAccess=true. Accessed 20 Mar 2017.

55. Sanghani RM, Carlin AL, Moler AK. Assessing success-a commentary on the necessity of outcomes measures. Subst Abuse Treat Prev Policy. 2015;10:20.

56. Schaub MP, Uchtenhagen A. Building a European consensus on minimum quality standards for drug treatment, rehabilitation and harm reduction. Eur Addict Res. 2013;19:314-24.

57. Nikolopoulos GK, Fotiou A, Kanavou E, Richardson C, Detsis M, Pharris A, et al. National income inequality and declining GDP growth rates are associated with increases in HIV diagnoses among people who inject drugs in Europe: a panel data analysis. PLOS ONE. 2015;10:e0122367.

58. Friedman SR, Pouget ER, Chatterjee S, Cleland CM, Tempalski B, Brady JE, et al. Drug arrests and injection drug deterrence. Am J Public Health. 2011:101:344-9.

59. Pharris A, Wiessing L, Sfetcu O, Hedrich D, Botescu A, Fotiou A et al. Humanimmunodeficiency virus in injecting drug users in Europe following a reported increase of cases in Greece and Romania, 2011. Euro Surveill. 2011;16: 
pii=20032. http://www.eurosurveillance.org/ViewArticle.aspx?Articleld=20032. Accessed 20 Mar 2017.

60. Nordt C, Stohler R. Incidence of heroin use in Zurich, Switzerland: a treatment case register analysis. Lancet. 2006;367:1830-4.

61. Abdul-Quader AS, Feelemyer J, Modi S, Stein ES, Briceno A, Semaan S, et al. Effectiveness of structural-level needle/syringe programs to reduce HCV and HIV infection among people who inject drugs: a systematic review. AIDS Behav. 2013;17:2878-92.

62. Emmanuelli J, Desenclos JC. Harm reduction interventions, behaviours and associated health outcomes in France, 1996-2003. Addiction. 2005;100:1690-700.

63. Strike C, Watson TM, Lavigne P, Hopkins S, Shore R, Young D, et al. Guidelines for better harm reduction: evaluating implementation of best practice recommendations for needle and syringe programs (NSPs). Int J Drug Policy. 2011;22:34-40

64. Haines A, Kuruvilla S, Borchert M. Bridging the implementation gap between knowledge and action for health. Bull World Health Organ. 2004;82:724-31.

65. Eurasian Harm Reduction Network. Methodology to assess and monitor access to harm reduction services. Vilnius: EHRN; 2014. http://www.harmreduction.org/sites/default/files/pdf/4_modules_glaossary_and_preface.zip. Accessed 20 Mar 2017

66. Fink A, Kosecoff J, Chassin M, Brook RH. Consensus methods: characteristics and guidelines for use. Am J Public Health. 1984;74:979-83.

67. Delbeca AL, Van de Ven AH, Gustafson DH. Group techniques for program planning: a guide to nominal group and Delphi processes. Glenview: Scott Foresman; 1975

68. Council of the European Union. Council conclusions on the implementation of the EU Action Plan on Drugs 2013-2016 regarding minimum quality standards in drug demand reduction in the European Union. Brussels: Council of the European Union; 2015. https://goo.gl//7NZK4. Accessed 20 Mar 2017.

69. Ball A, Des Jarlais DC, Donoghoe MC, Friedman SR, Goldberg D, Hunter GM, et al. Multi-city study on drug injecting and risk of HIV infection: a report prepared on behalf of the WHO International Collaborative Group. Geneva: World Health Organization; 1994. Programme on Substance Abuse. https:// extranet.who.int/iris/restricted/bitstream/10665/62037/1/WHO_PSA 94.4.pdf. Accessed 20 Mar 2017

70. Cire B. Global network will promote information exchange on HIV prevention in drug-using populations. NIDA Notes. National Institute on Drug Abuse; 1999. http://archives.drugabuse.gov/NIDA_Notes/NNVol13N5/ Global.html. Accessed 20 Mar 2017.

71. Aceijas C, Stimson GV, Hickman M, Rhodes T. Global overview of injecting drug use and HIV infection among injecting drug users. AIDS. 2004;18:2295-303.

72. Aceijas C, Friedman SR, Cooper HL, Wiessing L, Stimson GV, Hickman M. Estimates of injecting drug users at the national and local level in developing and transitional countries, and gender and age distribution. Sex Transm Infect. 2006;82 Suppl 3:iii10-7. http://www.ncbi.nlm.nih.gov/pmc/articles/ PMC2576733/pdf/iii10.pdf. Accessed 20 Mar 2017.

73. Mathers BM, Degenhardt L, Phillips B, Wiessing L, Hickman M, Strathdee SA, et al. Global epidemiology of injecting drug use and HIV among people who inject drugs: a systematic review. Lancet. 2008;372:1733-45.

74. WHO, UNODC, UNAIDS. Technical Guide for countries to set targets for universal access to HIV prevention, treatment and care for injecting drug users. Geneva: WHO; 2009. http://www.who.int/hiv/pub/idu/idu_target_setting_guide.pdf. Accessed 20 Mar 2017.

75. WHO. Consolidated guidelines on HIV prevention, diagnosis, treatment and care for key populations, Consolidated guidelines on HIV prevention, diagnosis, treatment and care for key populations. Geneva: WHO; 2014. https://goo.gl/QxWY3m. Accessed 20 Mar 2017.

76. UNODC. World Drug Report 2015. Vienna: UNODC; 2015. http://www.unodc. org/documents/wdr2015/World_Drug_Report_2015.pdf. Accessed 20 Mar 2017.

77. UNAIDS. Global AIDS Monitoring 2017-indicators for monitoring the 2016 United Nations political declaration on HIV and AIDS. Geneva: UNAIDS; 2017. http://www.unaids.org/sites/default/files/media_asset/2017-GlobalAIDS-Monitoring_en.pdf. Accessed 20 Mar 2017.

78. ICPR. World prison brief. London: Institute for Criminal Policy Research (ICPR); 2015. http://www.prisonstudies.org/world-prison-brief. Accessed 20 Mar 2017.

79. Hartnoll $R$, Avico U, Ingold FR, Lange $K$, Lenke L, O'Hare A, et al. A multi-city study of drug misuse in Europe. Bull Narc. 1989;41:3-27.

80. Simon R, Donmall M, Hartnoll R, Kokkevi A, Ouwehand AW, Stauffacher M, et al. The EMCDDA/Pompidou Group treatment demand indicator protocol: a European core item set for treatment monitoring and reporting. Eur Addict Res. 1999;5:197-207.
81. Stauffacher M, Kokkevi A. The Pompidou Group treatment demand protocol: the first pan-European standard in the field. Eur Addict Res. 1999;5:191-6.

82. Richardson C, Ancelle-Park R, Papaevangelou G. Factors associated with HIV seropositivity in European injecting drug users. The European Community Study Group on HIV in injecting drug users. AIDS. 1993;7:1485-91.

83. Richardson SC, Papaevangelou G, Ancelle-Park R. Knowledge, attitudes and beliefs of European injecting drug users concerning preventive measures for HIV. Eur J Epidemiol. 1994;10:135-42.

84. Schlumberger MG, Desenclos JC, Papaevangelou G, Richardson SC, AncellePark R. Knowledge of HIV serostatus and preventive behaviour among European injecting drug users: second study. European Community Study Group on HIV in injecting drug users. Eur J Epidemiol. 1999;15:207-15.

85. Wiessing LG, Toet J, Houweling $H$, Koedijk PM, van den Akker $R$, Sprenger MJW. Prevalentie en risicofactoren van HIV-infectie onder druggebruikers in Rotterdam. [Prevalence and risk factors of HIV infection among drug users in Rotterdam]. Bilthoven: RIVM; 1995. http://www.rivm.nl/bibliotheek/ rapporten/213220001.pdf. Accessed 20 Mar 2017.

86. Houweling H, Wiessing LG, Hamers FF, Termorshuizen F, Gill ON, Sprenger MJ. An age-period-cohort analysis of 50,875 AIDS cases among injecting drug users in Europe. Int J Epidemiol. 1999;28:1141-8.

87. Jager JC, Achterberg PW, Postma MJ, Houweling H. Comparative impact assessment of AIDS: between doomsday and complacency. AIDS. 1996; 10:238-40.

88. Rotily M, Weilandt C, Bird SM, Kall K, Van Haastrecht HJ, landolo E, et al. Surveillance of HIV infection and related risk behaviour in European prisons. A multicentre pilot study. Eur J Public Health. 2001;11:243-50.

89. Stover $\mathrm{H}$, Nelles J. Ten years of experience with needle and syringe exchange programmes in European prisons. Int J Drug Policy. 2003;14:437-44.

90. Stover H, Casselman J, Hennebel L. Substitution treatment in European prisons: a study of policies and practices in 18 European countries. Int J Prison Health. 2006;2:3-12. http://www.drogenforschung.de/pdf/volltexte_ pdf/nr18/subst_treatm_eupris.pdf. Accessed 20 Mar 2017.

91. Griffiths P, Mounteney J, Lopez D, Zobel F, Gotz W. Addiction research centres and the nurturing of creativity. Monitoring the European drug situation: the ongoing challenge for the European Monitoring Centre for Drugs and Drug Addiction (EMCDDA). Addiction. 2012;107:254-8.

92. Mounteney J, Griffiths P, Sedefov R, Noor A, Vicente J, Simon R. The drug situation in Europe: an overview of data available on illicit drugs and new psychoactive substances from European monitoring in 2015. Addiction. 2016,111:34-48

93. Wiessing L, Ncube F, Hedrich D, Griffiths P, Hope V, Gill N et al. Surveillance of infectious diseases in IDUs across the EU: information from the EU expert network. Euro Surveill. 2004;8:pii=2368. http://www.eurosurveillance.org/ ViewArticle.aspx?Articleld=2368. Accessed 20 Mar 2017.

94. Wiessing L. New EMCDDA toolkit for monitoring infectious diseases. Drugnet Europe. 2014;85:2. http://www.emcdda.europa.eu/system/files/ publications/785/Drugnet_85_weboptimised_461952.pdf. Accessed 20 Mar 2017.

95. Jager J, Limburg W, Kretzschmar M, Postma M, Wiessing L (eds). Hepatitis C and injecting drug use: impact, costs and policy options. EMCDDA: Lisbon; 2004. https://goo.gl/WgRoSB. Accessed 20 Mar 2017.

96. Wiessing L, Kraus L, Hay G, Rossi C, Frischer M, Jager J, et al. European network to develop policy relevant models and socio-economic analyses of drug use: consequences and interventions. Lisbon: EMCDDA; 2002. http://www.emcdda. europa.eu/html.cfm/index1376EN.html. Accessed 20 Mar 2017.

97. Godfrey C, Wiessing L, Hartnoll R (eds). Modelling drug use: methods to quantify and understand hidden processes. EMCDDA: Lisbon; 2000. http://www.emcdda.europa.eu/system/files/publications/922/Monograph6_ 159816.pdf. Accessed 20 Mar 2017.

98. Hartnoll RL. Drug epidemiology in the European institutions: historical background and key indicators. UN Bull Narc. 2003;55:53-72. http://www.unodc.org/pdf/bulletin/bulletin_2003_01_01_1.pdf\#page=60. Accessed 20 Mar 2017

99. Wiessing L, Hartnoll R, Rossi C. The epidemiology of drug use at the macro level: indicators, models and policy-making. UN Bull Narc. 2001;53:119-33. http://www.unodc.org/unodc/en/data-and-analysis/bulletin/bulletin_200101-01_1_page011.html. Accessed 20 Mar 2017.

100. Hartnoll R. Drug trends in the European Union. 1999. Epidemiologic trends in drug abuse. International epidemiology work group on drug abuse June 1999. Proceedings. p. 49-58. https://archives.drugabuse.gov/pdf/cewg/ IEWG699.pdf. Accessed 20 Mar 2017. 
101. Uhl A, Hunt G, van den Brink W, Stimson GV. How credible are international databases for understanding substance use and related problems? Int I Drug Policy. 2015;26:119-21.

102. Jones HE, Hickman M, Welton NJ, De AD, Harris RJ, Ades AE. Recapture or precapture? Fallibility of standard capture-recapture methods in the presence of referrals between sources. Am J Epidemiol. 2014;179:1383-93.

103. Zabransky T. On a search for useful indicators... or not? Addiction. 2015;110:741-3.

104. UNODC. Global Assessment Programme on Drug Abuse (GAP). 2003; UNODC. http://www.unodc.org/unodc/en/GAP/. Accessed 20 Mar 2017.

105. Hickman M, Taylor C, Chatterjee A, Degenhardt L, Frischer M, Hay G, et al. Estimating the prevalence of problematic drug use: a review of methods and their application. UN Bull Narc. 2002;54:15-32. https://www.unodc.org/ pdf/bulletin/bulletin_2002_01_01_Art2.pdf. Accessed 20 Mar 2017.

106. Nelson PK, Mathers BM, Cowie B, Hagan H, Des Jarlais D, Horyniak D, Degenhardt L. Global epidemiology of hepatitis B and hepatitis $C$ in people who inject drugs: results of systematic reviews. Lancet. 2011; 378:571-83.

107. Habicht JP, Victora CG, Vaughan JP. Evaluation designs for adequacy, plausibility and probability of public health programme performance and impact. Int J Epidemiol. 1999;28:10-8.

108. Wiessing LG, Denis B, Guttormsson U, Haas S, Hamouda O, Hariga F, et al. Estimating coverage of harm-reduction measures for injection drug users in Europe. 2001. Global Research Network On HIV Prevention In Drug-Using Populations - Third Annual Meeting.July 5-7, 2000, Durban. Bethesda: NIDA; 2001. https://goo.gl/BWHjSN. Accessed 20 Mar 2017.

109. EMCDDA. 2001 annual report on the state of the drugs problem in the European Union. Lisbon: EMCDDA; 2001. http://www.emcdda.europa.eu/ attachements.cfm/att_37276_EN_ar01_en.pdf. Accessed 20 Mar 2017.

110. Humphreys K. Commentary on Gustafson et al. (2013): can we know that addiction treatment has been improved without evidence of better patient outcomes? Addiction. 2013;108:1158-9.

111. Blystad H, Wiessing L. Guidelines for testing HIV, viral hepatitis and other infections in injecting drug users. EMCDDA manuals no 6. EMCDDA: Lisbon; 2010. http://www.emcdda.europa.eu/publications/manuals/testingguidelines. Accessed 20 Mar 2017.

112. Goltzman PM. Intervenciones desde la Reducción de Daños. Perspectivas y desafíos actuales. Memoria de encuentro, Buenos Aires 21-22 de junio 2016. Buenos Aires: Intercambios; 2016. http://intercambios.org.ar/wp-content/ uploads/2016/10/RD-perspectivas-y-desafios-2016-Intercambios.pdf. Accessed 20 Mar 2017.

113. Ritter A, Livingston M, Chalmers J, Berends L, Reuter P. Comparative policy analysis for alcohol and drugs: current state of the field. Int J Drug Policy. 2016;31:39-50

114. Belackova V, Ritter A, Shanahan M, Hughes CE. Assessing the concordance between illicit drug laws on the books and drug law enforcement: comparison of three states on the continuum from "decriminalised" to "punitive". Int J Drug Policy. 2017;41:148-57.

115. Frischer M, Bloor M, Finlay A, Goldberg D, Green S, Haw S, et al. A new method of estimating prevalence of injecting drug use in an urban population: results from a Scottish city. Int J Epidemiol. 1991;20:997-1000.

116. Jones HE, Welton NJ, Ades AE, Pierce M, Davies W, Coleman B et al. Problem drug use prevalence estimation revisited: heterogeneity in capturerecapture and the role of external evidence. Addiction. 2016;111:438-47.

117. Hay G, McKeganey N, Wiessing L, Bello PY, D'Ippoliti D, Domingo-Salvany A, et al. Methodological guidelines to estimate the prevalence of problem drug use on the local level. Lisbon: EMCDDA; 1999. https://goo.gl/9RK1hz. Accessed 20 Mar 2017.

118. Kraus L, Augustin R, Frischer M, Kummler $P$, Uhl A, Wiessing L. Estimating prevalence of problem drug use at national level in countries of the European Union and Norway. Addiction. 2003;98:471-85.

119. Frischer M, Hickman M, Kraus L, Mariani F, Wiessing L. A comparison of different methods for estimating the prevalence of problematic drug misuse in Great Britain. Addiction. 2001;96:1465-76.

120. Chatterjee S, Tempalski B, Pouget ER, Cooper HL, Cleland CM, Friedman SR Changes in the prevalence of injection drug use among adolescents and young adults in large U.S. metropolitan areas. AIDS Behav. 2011;15:1570-8.

121. Holmberg SD. The estimated prevalence and incidence of HIV in 96 large US metropolitan areas. Am J Public Health. 1996;86:642-54.

122. Cooper HL, Brady JE, Friedman SR, Tempalski B, Gostnell K, Flom PL. Estimating the prevalence of injection drug use among black and white adults in large U.S. metropolitan areas over time (1992-2002): estimation methods and prevalence trends. J Urban Health. 2008;85:826-56.
123. Brady JE, Friedman SR, Cooper HL, Flom PL, Tempalski B, Gostnell K. Estimating the prevalence of injection drug users in the U.S. and in large U.S. metropolitan areas from 1992 to 2002. J Urban Health. 2008;85:323-51.

124. Pouget ER, Friedman SR, Cleland CM, Tempalski B, Cooper HL. Estimates of the population prevalence of injection drug users among Hispanic residents of large US metropolitan areas. J Urban Health. 2012;89:527-64.

125. Hickman M, De AD, Jones H, Harris R, Welton N, Ades AE. Multiple paramete evidence synthesis - a potential solution for when information on drug use and harm is in conflict. Addiction. 2013;108:1529-31.

126. Tempalski B, Pouget ER, Cleland CM, Brady JE, Cooper HL, Hall HI, et al. Trends in the population prevalence of people who inject drugs in US metropolitan areas 1992-2007. PLoS ONE. 2013;8:e64789.

127. Pierce M, Bird SM, Hickman M, Millar T. National record linkage study of mortality for a large cohort of opioid users ascertained by drug treatment or criminal justice sources in England, 2005-2009. Drug Alcohol Depend. 2015;146:17-23.

128. Tempalski B, Cleland CM, Pouget ER, Chatterjee S, Friedman SR. Persistence of low drug treatment coverage for injection drug users in large US metropolitan areas. Subst Abuse Treat Prev Policy. 2010;5:23.

129. Stimson GV, Hickman M, Quirk A, Frischer M, Taylor C (eds.). Estimating the prevalence of problem drug use in Europe. Lisbon: EMCDDA/Pompidou Group; 1997. http://old.ntakd.lt/files/leidiniai/emcdda/6-Monographs/5Estimating.pdf. Accessed 20 Mar 2017.

130. Vickerman P, Martin NK, Hickman M. Understanding the trends in HIV and hepatitis C prevalence amongst injecting drug users in different settings-implications for intervention impact. Drug Alcohol Depend. 2012;123:122-31.

131. Martin NK, Vickerman P, Miners A, Foster GR, Hutchinson SJ, Goldberg DJ, et al. Cost-effectiveness of hepatitis $C$ virus antiviral treatment for injection drug user populations. Hepatology. 2012;55:49-57.

132. Kretzschmar M, Wiessing LG. Modelling the spread of HIV in social networks of injecting drug users. AIDS. 1998;12:801-11.

133. Kretzschmar $M$, Wiessing $L$. New challenges for mathematical and statistical modelling of HIV and HCV in IDUs. AIDS. 2008;22:1527-37.

134. Cousien A, Tran VC, Deuffic-Burban S, Jauffret-Roustide M, Dhersin JS, Yazdanpanah Y. Dynamic modelling of hepatitis $C$ virus transmission among people who inject drugs: a methodological review. J Viral Hepat. 2015;22:213-29.

135. Kaplan EH, O'Keefe E. Let the needles do the talking! Evaluating the New Haven needle exchange. Interfaces. 1993;23:7-26. https://goo.gl/50mafW. Accessed 20 Mar 2017.

136. de Vos AS, Prins M, Kretzschmar ME. Hepatitis C virus treatment as prevention among injecting drug users: who should we cure first? Addiction. 2015;110:975-83.

137. de Vos AS, Kretzschmar ME. The efficiency of targeted intervention in limiting the spread of HIV and hepatitis $C$ virus among injecting drug users. J Theor Biol. 2013;333:126-34.

138. Martin NK, Vickerman P, Grebely J, Hellard M, Hutchinson SJ, Lima VD, et al. Hepatitis $C$ virus treatment for prevention among people who inject drugs: modeling treatment scale-up in the age of direct-acting antivirals. Hepatology. 2013;58:1598-609.

139. de Vos AS, Prins M, Coutinho RA, van der Helm JJ, Kretzschmar ME. Treatment as prevention among injecting drug users; extrapolating from the Amsterdam cohort study. AIDS. 2014;28:911-8.

140. Paraskevis D, Paraschiv S, Sypsa V, Nikolopoulos G, Tsiara C, Magiorkinis G, et al. Enhanced HIV-1 surveillance using molecular epidemiology to study and monitor HIV-1 outbreaks among intravenous drug users (IDUs) in Athens and Bucharest. Infect Genet Evol. 2015;35:109-21.

141. Niculescu I, Paraschiv S, Paraskevis D, Abagiu A, Batan I, Banica L, et al. Recent HIV-1 outbreak among intravenous drug users in Romania: evidence for cocirculation of CRF14_BG and subtype F1 strains. AIDS Res Hum Retroviruses. 2015;31:488-95.

142. Paraskevis D, Nikolopoulos G, Fotiou A, Tsiara C, Paraskeva D, Sypsa V, et al. Economic recession and emergence of an HIV-1 outbreak among drug injectors in Athens metropolitan area: a longitudinal study. PLOS ONE. 2013:8:e78941. http://www.plosone.org/article/info\%3Adoi\%2F10.1371\%2Fjournal.pone.0078941. Accessed 20 Mar 2017.

143. Balode D, Skar H, Mild M, Kolupajeva T, Ferdats A, Rozentale B, et al Phylogenetic analysis of the Latvian HIV-1 epidemic. AIDS Res Hum Retroviruses. 2012;28:928-32.

144. Degenhardt L, Hall W. Extent of illicit drug use and dependence, and their contribution to the global burden of disease. Lancet. 2012;379:55-70. 
145. Hser Yl, Evans E, Grella C. Commentary on Degenhardt et al. (2014): Regional variation in the global burden of disease attributable to opioid dependence-where do the data come from and does population size matter? Addiction. 2014;109:1334-5.

146. Degenhardt L, Mathers B, Hall WD. Response to Hser et al. (2014): the necessity for more and better data on the global epidemiology of opioid dependence. Addiction. 2014;109:1335-7.

147. Wiessing L, Ferri M, Grady B, Kantzanou M, Sperle I, Cullen KJ, et al. Hepatitis $C$ virus infection epidemiology among people who inject drugs in Europe: a systematic review of data for scaling up treatment and prevention. PLoS ONE. 2014;9:e103345. http://journals.plos.org/plosone/article?id=10.1371/ journal.pone.0103345. Accessed 20 Mar 2017.

148. Wittchen HU, Jacobi F, Rehm J, Gustavsson A, Svensson M, Jonsson B, et al. The size and burden of mental disorders and other disorders of the brain in Europe 2010. Eur Neuropsychopharmacol. 2011;21:655-79.

149. Friedman SR, Tempalski B, Brady JE, Friedman JJ, Cooper HL, Flom PL, et al. Predictors of the degree of drug treatment coverage for injection drug users in 94 metropolitan areas in the United States of America. Int J Drug Policy. 2007;18:475-85.

150. Tempalski B, Flom PL, Friedman SR, Des Jarlais DC, Friedman JJ, McKnight C, et al. Social and political factors predicting the presence of syringe exchange programs in 96 US metropolitan areas. Am J Public Health. 2007;97:437-47.

151. Friedman SR, Cooper HL, Tempalski B, Keem M, Friedman R, Flom PL, et al. Relationships of deterrence and law enforcement to drug-related harms among drug injectors in US metropolitan areas. AIDS. 2006;20:93-9.

152. Wiessing L, Likatavicius G, Hedrich D, Guarita B, van de Laar MJ, Vicente J. Trends in HIV and hepatitis C virus infections among injecting drug users in Europe, 2005 to 2010. Euro Surveill. 2011;16:pii=20031 http://www. eurosurveillance.org/ViewArticle.aspx?Articleld=20031. Accessed 20 Mar 2017.

153. van den Berg C, Smit C, van Brussel G, Coutinho R, Prins M. Full participation in harm reduction programmes is associated with decreased risk for human immunodeficiency virus and hepatitis C virus: evidence from the Amsterdam Cohort Studies among drug users. Addiction. 2007;102:1454-62.

154. Hull MW, Wu Z, Montaner JS. Optimizing the engagement of care cascade: a critical step to maximize the impact of HIV treatment as prevention. Curr Opin HIV AIDS. 2012;7:579-86.

155. Yehia BR, Schranz AJ, Umscheid CA, Lo Re III V. The treatment cascade for chronic hepatitis $C$ virus infection in the United States: a systematic review and meta-analysis. PLoS ONE. 2014;9:e101554. http://journals.plos.org/ plosone/article?id=10.1371/journal.pone.0101554. Accessed 20 Mar 2017.

156. Strathdee SA, Beletsky L, Kerr T. HIV, drugs and the legal environment. Int J Drug Policy. 2015;26 Suppl 1:S27-32.

157. Bird SM, Hutchinson SJ. Male drugs-related deaths in the fortnight after release from prison: Scotland, 1996-99. Addiction. 2003;98:185-90.

158. OECD. OECD health statistics 2015-definitions, sources and methods. Paris: OECD; 2015. http://stats.oecd.org/wbos/fileview2.aspx?IDFile=587d75746ed6-4408-9c32-481d322936e6. Accessed 20 Mar 2017.

159. EMCDDA. Cost and financing of drug treatment services in Europe: an exploratory study. Lisbon: EMCDDA; 2011. http://www.emcdda.europa.eu/ attachements.cfm/att_143682_EN_TDSI11001ENC.pdf. Accessed 20 Mar 2017.

160. Ritter A, Hull P, Berends L, Chalmers J, Lancaster K. A conceptual schema for government purchasing arrangements for Australian alcohol and other drug treatment. Addict Behav. 2016;60:228-34.

161. Petersen LA, Woodard LD, Urech T, Daw C, Sookanan S. Does pay-for-performance improve the quality of health care? Ann Intern Med. 2006;145:265-72.

162. Mason T, Sutton M, Whittaker W, McSweeney T, Millar T, Donmall M, et al. The impact of paying treatment providers for outcomes: difference-indifferences analysis of the 'payment by results for drugs recovery' pilot. Addiction. 2015;110:1120-8.

163. McLellan AT, Kemp J, Brooks A, Carise D. Improving public addiction treatment through performance contracting: the Delaware experiment. Health Policy. 2008;87:296-308.

164. Guyatt GH, Oxman AD, Vist GE, Kunz R, Falck-Ytter Y, Alonso-Coello P, et al. GRADE: an emerging consensus on rating quality of evidence and strength of recommendations. BMJ. 2008;336:924-6.

165. Broome KM, Simpson DD, Joe GW. Patient and program attributes related to treatment process indicators in DATOS. Drug Alcohol Depend. 1999;57:127-35.

166. Gossop M, Marsden J, Stewart D. NTORS After Five Years. The National Treatment Outcome Research Study - Changes in substance use, health and criminal behaviour during the five years after intake. London: National Addiction Centre; 2001.
167. Godfrey C, Stewart D, Gossop M. Economic analysis of costs and consequences of the treatment of drug misuse: 2-year outcome data from the National Treatment Outcome Research Study (NTORS). Addiction. 2004;99:697-707.

168. McKeganey N, Bloor M, Mclntosh J, Neale J. Key findings from the Drug Outcome Research in Scotland (DORIS) study. Glasgow: University of Glasgow - Centre for Drug Misuse Research; 2008. http:// substanceuseresearch.org/wp-content/uploads/2016/02/DORIS-Key.pdf. Accessed 20 Mar 2017.

169. Donmall M, Jones A, Davies L, Barnard M. Summary of key findings from the Drug Treatment Outcomes Research Study (DTORS). Research Report 23 (summary). UK: Home Office; 2009. https://www.gov.uk/government/ uploads/system/uploads/attachment_data/file/116599/horr23.pdf. Accessed 20 Mar 2017.

170. Jones A, Donmall M, Millar T, Moody A, Weston S, Anderson T, et al. The drug treatment outcomes research study (DTORS): final outcomes report 3rd edition. UK: Home Office; 2009. http://citeseerx.ist.psu.edu/viewdoc/ download?doi=10.1.1.604.904\&rep=rep1\&type=pdf. Accessed 20 Mar 2017.

171. Mant J. Process versus outcome indicators in the assessment of quality of health care. Int J Qual Health Care. 2001;13:475-80. http://intqhc. oxfordjournals.org/content/13/6/475.full-text.pdf. Accessed 20 Mar 2017.

\section{Submit your next manuscript to BioMed Central and we will help you at every step:}

- We accept pre-submission inquiries

- Our selector tool helps you to find the most relevant journal

- We provide round the clock customer support

- Convenient online submission

- Thorough peer review

- Inclusion in PubMed and all major indexing services

- Maximum visibility for your research

Submit your manuscript at www.biomedcentral.com/submit
) Biomed Central 